Abstracta Iranica Iranica

Revue bibliographique pour le domaine irano-aryen

Volume 28 | 2007

Comptes rendus des publications de 2005

\title{
Zoroastrian rituals in context. Leiden-Boston, Brill, 2004, X-737 p., 16 p. de pl. ill.
}

\section{Rédaction}

\section{(2) OpenEdition}

1 Journals

\section{Édition électronique}

URL : http://journals.openedition.org/abstractairanica/11862

DOI : 10.4000/abstractairanica. 11862

ISSN : 1961-960X

Éditeur :

CNRS (UMR 7528 Mondes iraniens et indiens), Éditions de l'IFRI

\section{Édition imprimée}

Date de publication : 15 mai 2007

ISSN : 0240-8910

\section{Référence électronique}

Rédaction, «Zoroastrian rituals in context. Leiden-Boston, Brill, 2004, X-737 p., 16 p. de pl. ill. », Abstracta Iranica [En ligne], Volume 28 | 2007, document 244, mis en ligne le 18 septembre 2007, consulté le 25 septembre 2020. URL : http://journals.openedition.org/abstractairanica/11862 ; DOI : https://doi.org/ 10.4000/abstractairanica.11862

Ce document a été généré automatiquement le 25 septembre 2020

Tous droits réservés 


\title{
Zoroastrian rituals in context. Leiden- Boston, Brill, 2004, X-737 p., 16 p. de pl. ill.
}

\author{
Rédaction
}

1 Cette ouvrage est la publication des actes d'un colloque sur les rituels zoroastriens, tenu à Heidelberg en avril 2002 ("The Heidelberg Symposion on Zoroastrian Rituals in Context", Internationales Wissenschaftsforum Heidelberg, 10-13/04/2002). Ci-dessous la liste des articles de cette publication. Certains pourront faire l'objet d'une recension dans le prochain numéro d'Abs. Ir.

2 Michael Stausberg, "Contextualizing the Contexts. On the Study of Zoroastrian Rituals" (pp. 1-56).

3 Modelling Theory - Theoretical Approaches : Burkhard Gladigow, "Sequenzierung von Riten und die Ordnung der Rituale” (pp. 57-76). Jan Snoek, “'Initiations' in Theory and in Zoroastrianism" (pp. 77-98). Jens Kreinath, "Meta-Theoretical Parameters for the Analysis and Comparison of two Recent Approaches to the Study of the Yasna" (pp. 99-136).

4 Comparative Studies: James W. Boyd \& Ron G. Williams, "The Art of Ritual in a Comparative Context" (pp. 137-152). Dorothea Lüddeckens, "Bruch und Kontinuität in Todesritualen. Beobachtungen $\mathrm{zu}$ westeuropäischern und zoroastrischen Bestattungen" (pp.153-172). Gernot Windfuhr, "Zoroastrian and Taoist Ritual: Cosmology and Sacred Numerology" (pp. 173-232). Antonio Panaino, "Aspects of the 'Interiorization' of the Sacrifice in the Zoroastrian Tradition” (pp. 233-252).

5 Ritual Texts - Rituals In Texts : P. O. Skjærvø, "Smashing Urine: On Yasna 48.10" (pp. 253-282). Jean Kellens, "Finalités sacrificielles dans l'Avesta récent” (pp. 283-290). Almut Hintze, "On the Ritual Significance of the Yasna Haptanhaiti" (pp. 291-316). Philip Kreyenbroek, "Terms for Ritual and Rituals in the Nerangestan" (pp. 317-332). Shaul Shaked, "The Yasna Ritual in Pahlavi Literature" (pp. 333-344). 
6 Ritual Performances and Practices: Albert de Jong, "Sub specie maiestatis: Reflections on Sasanian Court Rituals" (pp. 345-388). Feroze Kotwal \& Jamsheed K. Choksy, "To Praise the Souls of the Deceased and the Immortal Spirits of the Righteeous Ones: The Staomi or Stūm Ritual's History and Functions" (pp. 389-402). Ramiyar P. Karanjia, "The Bāj-dharnā (Drōn Yašt) and its place in Zoroastrian Rituals" (pp. 403-424). M. Vitalone, "Fires and the Establishment of ātaš bahrāms in the Zoroastrian Tradition” (pp. 425-442). Sarah Stewart, “The Ātaš nu gìt. Areconstitutive Ritual of Recital" (pp. 443-460). C. G. Cereti, "Prejudice vs. Reality. Zoroastrians and their Rituals as Seen by two 19th Century Italian Travellers" (pp. 461-480). M. Giara, R. P. Karanjia \& M. Stausberg, "Manekji on the Religious/Ritual Practices of the Iranian Zoroastrians: An English Translation of a Passage from his Travel Report in Gujarati (1865)" (pp. 481-516).

7 The Interaction of Ritual Traditions : Werner Sundermann, “Zarathustra der Priester und Prophet in der Lehre der Manichäer" (pp. 517-530). Sabine Kalinock, "Supernatural Intercession to Earthly Problems: Sofreh-Rituals Among Shiite Muslims and Zoroastrians in Iran" (pp. 531-546). Beate Schmermbeck, “O Herr, erhöre unser Monāğāt': Zarathustrische Traditionslinien einer persischen Gebetsgattung zwischen Indien und Iran" (pp. 547-562). Robert Langer, "From Private Shrine to Pilgrim-Center: The Spectrum of Zoroastrian Shrines in Iran" (pp. 563-592).

8 Ritual Change - Changing Ritual: Dietrich Huff, "Archaeological Evidence of Zoroastrian Funerary Practices" (pp. 593-630). Katayoun Mazdapour, "Kontinuität und Wandel in den Ritualen der iranischen Zarathustrier" (pp. 631-652). Michael Stausberg, "Monday-Nights at the Banaji, Fridays at the Aslaji: Ritual Efficacy and Transformation in Bombay City" (pp. 653-718).

INDEX

Thèmes : 6.1. Zoroastrisme

\section{AUTEURS}

\section{RÉDACTION}

Directeur de la revue et secrétariats (Paris et Téhéran) 